\title{
When theory and practice clash: Participatory governance and management in Takht-e Soleyman
}

\begin{abstract}
Purpose - This paper aims at analyzing the state of participatory governance and management together with the sustainable development principles in a rural cultural landscape, focusing on the specific case of Takht-e Soleyman World Heritage Site (WHS).

Design/methodology/approach - The paper presents the results of an empirical study carried out within the boundaries of a well-defined Iranian location, the Takht-e Soleyman WHS. It is based on a rigorous theoretical analysis, accompanied by in-depth interviews with the key actors in the heritage management and governance sectors, and large-scale surveys of the local population through the circulation of a questionnaire.

Findings - A measurable difference between the demonstrated and accepted theory and the participatory governance and management system implemented in Takht-e Soleyman WHS was observed, where the local community influence was found to be rather insignificant. Although the management plan of the site contains explicit clauses recommending and specifying the role of local community participation, strategies and mechanisms for implementing these measures are clearly under present.

Originality/value - Participatory governance and management in a rural cultural landscape WHS are challenging concepts and the instances of their implementation require thorough analysis. The study detailed in this paper makes a valuable contribution to the debate on the design and implementation of participatory governance and management systems in this field by examining the actual extent of successful implementation of theoretical values in the case of Takht-e Soleyman WHS and identifying the key factors, which contribute to this state.
\end{abstract}

Keywords Participatory governance and management, Rural cultural landscape, Sustainable development, Takht-e Soleyman WHS

Type of paper Research paper

\section{Introduction}

This paper studies the role of local community participation in achieving sustainable development goals in rural cultural landscapes. The study focuses on the case of Takht-e Soleyman WHS in Iran, which is considered a particularly interesting rural cultural landscape (Dailoo and Pannekoek, 2008; Bemanian et al., 2010). Takht-e Soleyman sacred heritage indicates that there has been human settlement in this area for about three millennia. However, the mountainous geographical location and harsh climate of Takht-e Soleyman reveals that it has not been chosen as a convenient habitat, but rather as an inspiring natural environment for humans to express symbols of their faith. Hence, this place is a representation of the successful use of natural environmental landscape planning over a significant span of time. Additionally, it is a testimony of the continuation of a cult related to fire and water over a period of about 2500 years.

The theoretical path of this research is developed alongside the increasing consideration for participatory governance and management in both sustainable development (Fraser et al., 2006) and cultural heritage (Fowler, 2002; Millar, 2006). The shift in the paradigms of governance has resulted in a change in the role of citizens, from formerly helpless and ineffective beneficiaries of decisions taken by the government into active participants and collaborators working towards the achievement of common 
outcomes (Ostrom, 1993). Moreover, community-driven development is considered to be an effective way to provide infrastructure and social services, stimulating economic activity and resource management, empowering poor people, and improving governance (Dongier et al., 2003). Similarly, the development of cultural landscapes to successfully function as a part of our heritage (Antrop, 2005), as a result of the interactions between humans and nature (Sauer, 1925), and as a holistic system of integrated social, cultural, economic and environmental values (Von Droste et al., 1995; Palang et al., 2000) requires a thorough analysis of collaborative governance in its implementation.

The recently published policy documents and ongoing debates have repositioned the general public at the center of sustainable development goals (UNCED 21, 1992; UNCSD, 2012). Similar trends are observed in the management of cultural heritage with a move towards local community engagement, as emphasized in the EU Presidency conference on Heritage Commons towards a Participative Heritage Governance in the Third Millennium (2014), where the social dimension of heritage, community-led development and the possible synergies across several different stakeholders were highlighted and discussed. Although cultural heritage has been considered as a driver for development in many policy documents, there is still a gap between the theory and practice of cultural heritage management in many parts of the world (Pereira Roders and Van Oers, 2011).

Thus, within this framework, the present paper investigates whether the case of the Takht-e Soleyman WHS in Iran could be considered a case of collaborative governance based on the actual involvement of the local community. Moreover, it focuses on identifying the degree of participation achieved in the site through the use of available tools, methodologies, and policies of rural cultural landscapes with consideration of the relevant challenges in developing countries.

Hence, the paper aims at answering the following research questions:

1- What are the challenges in implementing a suitable participatory governance model aimed at promoting a sustainable development approach in a rural cultural landscape?

2- Is the Takht-e Soleyman system of governance consistent with the participatory governance model for sustainable development in a rural cultural landscape?

3- If not, what are the shortcomings and necessary corrective measures?

On the basis of a deep theoretical examination, the investigation has been developed by including the reflections of stakeholders at the levels of both management and of the local community, looking for the patterns present within the collected data and defining the relationships of those patterns through an overall assessment.

The literature review is based on academic and policy documents relating to the governance and management of cultural heritage, cultural landscapes, and rural cultural landscapes through a sustainable development perspective. The empirical research was carried out by studying both the qualitative and quantitative data through a questionnaire survey conducted within the local community, and in-depth interview with eight key managers and experts of Takht-e Soleyman. For the analysis of the data collected through the questionnaires, the SPSS software was used.

The paper is structured in six sections. Following the introduction, the second section is dedicated to a theoretical overview of the argument. The third section presents the case of Takht-e Soleyman WHS and its features, followed by the fourth section, which presents the results of the empirical research. The fifth section discusses the outcomes of the research, and the last section provides concluding remarks.

\section{Cultural heritage and sustainable development in the context of participatory governance}


Over the past few decades, several forces like globalization and democratization have delineated a complex system of social changes. The expectations of citizens to influence the decisions affecting them have forced policy-makers to take into account issues related to the role of societal actors and social partners in the process of policy-making. These changes have established systems of collective decisionmaking and brought forth demands for new forms of governance (Kooiman, 1993; Chhotray and Stocker, 2009). The failure of traditional hierarchical and authoritarian methods of government in response to the new social and global context has resulted in the development of a more practical concept of governance attributed to a rather open, collaborative and participatory style of government (Rosenau, 1992; Fischer, 2006). In the former approach, the communities were regarded as dependent and incapable of influencing their fate, while in the latter approach citizens take responsibility for what happens around them as much as possible. Thus, they are not viewed as clients who receive what others who control the system provide for them, but are considered to be co-producers of their own education, safety, health, and well-governed communities (Ostrom, 1993).

The decision-making process in a collaborative network is naturally influenced both by the common value system of the network itself and by the individual value system of each partner (Camarinha-Matos and Macedo, 2010). Thus, the process of collective decision-making requires rules about who can decide what, and how decision-makers are to be made accountable (Chhotray and Stocker, 2009). It can be a cooperation between public and private partners in which the role of public parties changes according to the jurisdictional level (Swensen and Senbro, 2013), or a series of choices regarding a wider range of participation between the public and private actors, putting stress on the existence of many varying patterns of interaction being possible among them (Dewulf et al., 2013).

Over time, it has become clear that a governance approach based on a participatory perspective is necessary to successfully implement sustainable development policies.

Sustainable development was popularized in a report published by the World Commission on Environment and Development, in 1987, also known as the Brundtland report; and was defined as a development which meets the needs of the present without compromising the ability of future generations to meet their own needs. In the period since then, the theoretical perception of sustainable development has increasingly emphasized the importance of community engagement, and finally the need for cultural integration.

The Rio declaration (UNCED, 1992) emphasizes the participation of citizens as an important ingredient of effective development policy for moving toward sustainable development goals. Community-driven development is a development approach that provides social and infrastructural services, organizes economic activity and resource management, empowers poor people, improves governance, and enhances security of the poorest (Dongier et al., 2003). Principles of inclusiveness and global ethics enable even the most marginalized individuals and groups to participate in development processes and benefit from them (Hens, 2005). Therefore, in order to consider the policies, it is necessary to invest largely in the people and in increasing their awareness, rather than inducing them by the fear of being overwhelmed (Donato, 2008).

Recently expressed in 'The Future We Want', the outcome of UN Conference on Sustainable Development (UNCSD) in 2012, people are considered to be at the center of sustainable development. Indeed, it is stated that collaborative management should be finalized by policy makers and be executed by all the stakeholders; however it should be formally accepted and well perceived by local people as the main stakeholders, and as the final goal of local sustainable development.

Sustainable development in economic, environmental and social dimensions is cultural-sensitive (Bandarin at al., 2011). According to the UN System Task Team on the post-2015 UN Development Agenda (UNESCO, 2012), development interventions that are responsive to the cultural context and the peculiarities of a place and its community, and promote a human-centered approach to development are most effective in yielding sustainable, inclusive and equitable outcomes. 
Culture could be incorporated in sustainable development plans through integrating cultural policies in public policy making (Throsby, 2012). Therefore, the role of culture is not confined to cultural expressions for raising environmental concerns, or the revenues that culture brings to economy, but exists as the incorporation of a cultural perspective in all public policies. This process makes sustainable development plans consistent with cultural features of the area or, in other words, guarantees that the sustainable development process has a soul (UCLG and Barcelona City Council, 2009).

In the context of sustainable development, specific attention has been devoted to the features of cultural landscapes. While its conceptualization in the academic and scientific field was formed in the mid- $19^{\text {th }}$ century, the concept of a cultural landscape was introduced in policy documents starting in 1992, through a new category being issued in the UNESCO World Heritage List (Fowler, 2002). Cultural landscapes are holistic systems of integrated values (Sauer, 1925) situated critically at the interface between nature and culture (including tangible and intangible heritage), and biological and cultural diversity (Von Droste et al., 1995; Palang and Fry, 2003; Belluso, 2012). They represent a closely woven net of relationships, the essence of culture and people's identity (Vos and Meekes, 1999). Landscapes are symbols of the growing recognition of the fundamental links between local communities and their heritage, and mankind and its natural environment (Rossler, 2006), as well as, drivers of local socio-economic development (Termorshuizen and Opdam, 2009). They have several alternative futures that depend on management decisions made today. The choice between these alternatives depends on the values and evaluations associated with each landscape (Palang et al., 2000). In this regard, UNESCO Historic Urban Landscape Recommendation (2011) elaborates a landscape approach, which would be useful in developing the management vision based on preservation aspects as well as socio-economic impacts, intangible features of heritage, environmental aspects, inclusion of different stakeholders and heritage communities.

The interfaces between the dimensions of cultural landscape and sustainable development are grounded in two main perspectives.

The first interface is culture as a constituent of a cultural landscape and a driver for sustainable development (UN System Task Team on the post-2015 UN Development Agenda, 2012) which is effective through the development of the cultural sector itself i.e. heritage, creativity, cultural industries, crafts, cultural tourism (Besana, 2013) and ensuring that culture has its rightful place in all public policies, particularly those related to education, economy, science, communication, environment, social cohesion and international cooperation.

According to UN System Task Team on the post-2015 UN Development Agenda (2012), culture-led development also includes a range of non-monetized benefits, such as greater social inclusiveness and rootedness, resilience, innovation, creativity and entrepreneurship for individuals and communities, and the use of local resources, skills and knowledge. In this perspective, enhancing the cultural sector itself contributes to strengthening the social capital of a community (Murzyn-Kupisz and Dziazek, 2013) and fosters trust in public institutions.

The second interface relfects the role of the human being in both the cultural landscape and sustainable development perspectives. The recent acceptance of sustainable development puts humans at the center of development, while the modern characterization of landscape, indicates that it is formed in the mindset of the observer. As reflected by Greffe (2010) the traditional recognition of landscapes as a form of visualization in paintings and maps evolved to become a subjective form of content, where changes occur with the position of the viewer, or even better, the "flaneur"; a person leisurely strolling through its streets. Therefore, the cultural landscape is inherited from the past and can bridge the human being and the outer world through perceptions and system of beliefs.

Thus, the cultural legacies inherited by a cultural landscape are regarded as a fundamental resource for local sustainable development. On the other hand, the significance of the human factor in both characterizations confirms a demand to reorient the governance and management towards a participatory approach. 
As argued by many scholars, the governance and management of a cultural landscape requires a bottom-up approach, through the active participation of local communities (Murzyn-Kupisz and Dziazek, 2013; Yung and Chan, 2011; Selman, 2004). The engagement of the local community in the governance and management of landscape will integrate the traditional knowledge with the manifold relations people have towards the perceivable environment and the symbolic meaning it generates, offering valuable considerations for more sustainable planning and management of future landscapes (Antrop, 2005; Millar, 2006).

The need for a participatory governance and management approach in a cultural landscape is even more evident in the case of rural cultural landscapes.

The reason for this is that the concepts of rural character and the perceptions of rurality are often intertwined with the close connections of the rural community (Halfacree, 1995). This could not only be considered to occur amongst the community itself, but also between the community and the place (Antrop, 2005). Place attachment reflects the level of social involvement and individual commitment to place, particularly in rural communities where residents are more likely to be satisfied with their community (as place) than urban dwellers (Hummon, 1992). Therefore, it requires an understanding of what influences public acceptance and awareness to effectively implement planning strategies. One potential influence is place attachment, a positive emotional bond that develops between individuals or groups and their environment (Giuliani and Feldman, 1993; Lokocz et al., 2011).

Hence, the governance and management of rural cultural landscapes is a quite complex issue considering their characteristics, their social, cultural, economic and environmental values, the interactions of human beings with nature, as well as, the various perspectives from which the cultural landscape could be interpreted. The combinations of these factors create a value system (Vos and Meeks, 1999; Cristina Heras et al., 2013) that could be interpreted through static and dynamic approaches. The governance and management of rural cultural landscapes for sustainable development would be based on integrated approach to all values of the cultural landscape by assessments through inter- or transdisciplinary cooperation (Palang et al., 2005; Rio Declaration, 1992). These interpretations can be used as guidelines for planning, governing, managing and measuring the results (Mitchell et al., 2009). In this respect, the value-system process in terms of the rational relationship between the administrators and the local community is important, since it maintains the active role and participation of both actors in all stages of cultural heritage governance and management (Perkin, 2010; Smith et al., 2003).

Therefore, in rural cultural landscapes the governance system should be based on participatory policies with regard to the specific values of the region. The participatory approach of governance will result in valorization of the unique characteristics attributed to the rural cultural landscapes within the context of sustainable development.

Consistently, rural cultural landscapes need an integrated management system with a visionary scope of joint economic and cultural development in both the medium and long terms. The development of such historic areas relies on a rehabilitation process to properly engage the local community and ensure the effective management of all the heritage resources. The valorization of cultural heritage in those historic areas would generate positive externalities, which can also benefit neighborhood areas by providing greater social cohesion. (Cervelló-Royo et al, 2012).

This approach is functional for improving the cultural and economic performance of the site and enhancing the territory in terms of cultural knowledge, social belonging, promotion of tourism and entrepreneurial development (Donato and Badia, 2013). In terms of WHSs, the complexity of governance and management is mirrored in the protection of the universal values of the cultural landscape for both present and future generations, while matching local/regional/national situations with global considerations through participatory policies. 
Tourism as a driver of economic development in WHSs may result in damage to the existing heritage and resources, if not managed properly. The proper management, therefore, should ensure the long-term compatibility of the area and employment opportunities, enhance the social cohesion and quality of life of local communities by involving them in planning and management, and minimize the negative externalities of mass tourism to protect both cultural and biodiversity (Cervelló-Royo and Peiró-Signes, 2015). Accordingly, the proper management of WHSs requires clear strategies and effective methods for planning, designing, executing them in order to use the potential of the site in development, while preserving and enhancing its cultural significance (Pereira Roders and Van Oers, 2011). As a key action for participatory management, it is necessary to develop competencies among actors of the WHSs (Donato and Badia, 2013) by raising awareness, through mechanisms like education and training programs.

\section{The case of Takht-e Soleyman WHS}

Takht-e Soleyman is a typical rural cultural landscape in the Northwestern part of Iran (Figure 1) that has been considered a sacred place for millennia. The sanctity of this area was associated with natural features like warm water springs, which were mystifying in the past, and several geological features formed by the sedimentation of travertine springs. The significance of this landscape lies in the relationship between cultural and natural features that is reflected in the lifestyle and local beliefs of the inhabitants. In such an area, cultural identity is strongly associated with the ways in which people interact with the landscape (Waterton, 2005).

\section{Please insert Figure 1. here}

Takht-e Soleyman was registered in the UNESCO World Heritage List in 2003. The focus of the nomination is a fortified oval built around a natural lake situated in a valley surrounded by mountain ranges. Like the nearby and earlier site of Zendan-e Soleyman (Zendan Mountain), existence of the site is connected to the lake, a calcareous artesian well, whose sediments have made the site rise more than 60 meters above the ground level of the valley. The hollow, volcanic mountain, called Zendan-e Soleyman (Solomon's Prison) is surrounded by the remains of temples or shrines, dated to the first millennium BC (Osten \& Naumann, 1959). The crater was once full of water, but has later dried out. Some constructions on the mound itself dates back to the early Achaemenian dynasty (559-330 BC), and there are traces of settlement activity from the Parthian period. With the arrival of the Sasanians (5th century AD), Zendan-e Soleyman lost its importance in favor of Takht-e Soleyman (Naumann, 1977).

In Figure 1, No. 1 indicates the core zone of the UNESCO WHS while Nos. 2 to 7 include six other connected ancient elements in the buffer zone.

\section{Please insert Figure 2. here}

The limit of the site and protected areas were fixed by Mr. Mohammad Mehryar and Mahmoud Mousavi's studies and reports as well as those submitted to the ICHO by its office in the West Azerbayjan Province.

The universal values include several outstanding features. The royal architecture was created by the Sasanians (224-651 AD) in a harmonious composition inspired by their natural context and its influence architecture in the Islamic period, but also in other cultures. It exemplifies a Zoroastrian sanctuary (one of the early monotheistic religions of the world), integrated with Sasanian palatial architecture, a 
composition, which can be seen as a prototype. Moreover, it represents the continuation of a faith related to fire and water and the association of natural features with myths and legends over a period of some two and a half millennia.

Fire and water have been among the respected natural elements for the Iranian people since ancient times. In pre-Islamic architecture, fire was present near water resources, without any harm to nature. Worship places of fire and water were built close to each other. Fire was conceived a divine messenger between the physical and meta-physical world. While, water was considered the source of life and was believed to be the human passage the purer world. Accordingly, volcanic regions were of particular interest, especially where there was the presence of water as it was the case of Takht-e Soleyman embodying Azargoshnasb Fire Temple next to Anahita Temple.

\section{Please insert Figure 3. here}

This area is rich for its cultural diversity deriving form the diverse ethnic groups, cults, dialects, traditions, music, clothing, etc., many of which are associated with the natural context.

The economy in the area is based on agriculture, animal husbandry, beekeeping, mining (the area is surrounded by gold and precious stone mines), and handicrafts (especially carpet weaving); and tourism represents an emerging industry. Takht-e Soleyman WHS has significant capacity to attract different types of tourists such as cultural tourists, eco-tourists, geo-tourists, health-tourists (for warm mineral springs) and religious/belief tourism (for the Azargoshnasb Fire Temple or the believers of energy centers in this area).

The in-site observations and feedback from the technical staff of the main site reflected a number of challenges related to the governance and management of this site. The technical staff consulted were mainly experts in the fields of conservation, archaeology, and architecture.

The rural situation of the area implies a slow pace of development and marginalization of the local community. This fact is implied by the insufficient infrastructures for tourism, the lack of focus on tangible and intangible local cultural endowments, and by the decline in the feeling of attachment to the place, as well as, limited local job opportunities and emigration of the younger generations.

It was necessary to conduct a review of the relevant national documents and the WHS management plan to understand the governance and management systems in this place, and to clarify the legislative and normative framework, which has influenced the present situation.

The director of Takht-e Soleyman WHS is nominated by the General Office of Iranian WHSs (located in Tehran) in accordance with Deputy of Cultural Heritage of Iran Cultural Heritage, Handicrafts and Tourism Organization (ICHHTO), and the provincial office of the ICHHTO (West Azerbayjan province). Finally, the position is officially appointed by the head of central office of ICHHTO in Tehran. A steering committee composed of five experts in the fields of archaeology, conservation, history and architecture works closely with the director of Takht-e Soleyman site in decision-making, planning for preservation and conservation, research activities, and communication. In the history of management of this site, the role of this committee has sometimes been undervalued, but at present the committee is getting more involved in the management process. The following offices are in charge of the management of Takht-e Solyeman WHS: the office of the director, the office of protection and restoration, the office of finance and logistics, the office of research and technical support, and the office of presentation and publication. For the moment, the last two offices have limited activity. At the time of conducting this research the staff 
numbers no more than fifteen people, including: experts, guards, military guard, driver, service men, ticket seller, and accountant.

There is no considerable conflict of behavior among governmental organizations in the management of this area. Any development activities and changes initiated by organizations within the limitation of the UNESCO zones have to be approved by ICHHTO, in order not to disturb the universal values of the site. Therefore, the institutional segmentation is not an important burden in the management and preservation of Takht-e Soleyman WHS. This is a privilege for the cultural landscape in order not to lose its integrity and authenticity against the changes imposed by development activities.

Furthermore, the importance of public participation is further stressed in national and regional policy documents (e.g. National Development Vision $1404^{[\mathrm{i}]}$, the National Plan for Tourism Development, Development Vision for West Azerbayjan Province), as well as, in the national legislation currently in place (e.g. Iranian Cultural Heritage Organization Charter, 1988). This represents a legislative foundation for participatory governance and management of the cultural heritage ${ }^{[i]}$.

In addition, the Takht-e Soleyman site management plan foresees initiatives for raising the awareness of local authorities and the public about the values of the site, and the aims and importance of sustainable development.

\section{The empirical research}

The empirical research carried out at Takht-e Soleyman WHS examined the consistency between theory and practice in terms of participatory governance and management of the site. It was conducted in two stages: firstly by interviewing the key people associated with the management of the WHS, and secondly by means of a questionnaire survey conducted among the local community. The interviews and questionnaire were instruments that enabled us to understand the degree of collaboration between the community and the management team and the stakeholders' perceptions.

Consistent with the focus of this research, the empirical research has been developed based on a participatory approach addressing a process of sequential reflection and action. This approach enabled us to see the realities from the perspective of different groups of stakeholders and seek their support for valorization of cultural heritage in that area. Hence, the findings of empirical study would be considered in making a realistic platform for further research and planning.

That is, a top-down approach was employed through in-depth interviews with the key cultural heritage managers to recognize their opinions about participatory governance and management concerns of Takhte Soleyman, while the questionnaire survey conducted was part of a bottom-up approach to reveal management issues.

The in-depth qualitative interviews were conducted with the key persons who were/are in charge of the governance and management of heritage sites in Iran, including the deputy of ICHHTO and the former director of Takht-e Soleyman WHS for more than 20 years. All of the interviews were carried out in person. The recorded interviews were fully transcribed and further coded to capture key concepts of the argument.

This query was organized to identify the interviewees' viewpoints about the state of the governance and management of the site through three open-ended questions:

1- Does 'community engagement' play a crucial role in valorizing cultural heritage for local sustainable development in Takht-e Soleyman cultural landscape?

2- Are there specific provisions or actions realized in the Takht-e Soleyman WHS, which encourage social and economic development through promoting community involvement in activities related to cultural heritage? 
3- What are the barriers against collective management of cultural heritage in the Takht-e Soleyman WHS?

The first question, which reflected the importance of participation of the local community from the interviewees' points of view, showed that all of them fully acknowledged the importance of collective management of cultural heritage for sustainable development. The interesting outcome was their emphasis on the fact that sustainable development in this area would not be realized unless all the stakeholders, including public and private sectors, are involved. As mentioned by one of them, "sustainable development is from and for the people"; another interviewee stated that "a developed society in terms of economic and environmental issues is a society that has formerly been developed in social and cultural dimensions". In spite of this positive approach, the responses to the second question revealed that considerable inclusion of local community in governance and management of this region has not been achieved. However, there is a clear indication in Iranian cultural heritage legislation - like in the Cultural Heritage Organization Charter No. 3487-Qaf Dated July 19, 1988 - about the importance of people in identification, conservation, and revival of the cultural heritage, and in their supervision of the heritage itself; though it seems that the legislation has not been put into effect in present situation. Therefore, considerations, which are consistent in theory and interviewees statements, are nevertheless absent in the governance and management in place. Consequently, a missing link was recognized between prescriptions at legislative and normative level, and realities of governance and management in the WHS.

Through the third question, an attempt was made to discover the above-mentioned missing link. According to the points described in the interviews, the main reasons for lack of participation of local population are: lack of sufficient awareness of the role of cultural heritage in local development both at local community and in different levels of management, short-term policies and plans which fluctuate according to the changes in political orientations, and a government-centered system (including legislation, implementation, monitoring, etc.) resulting in the absence of public and private sectors, and prioritization of development dimensions other than the cultural ones, specifically cultural heritage.

Along with the interviews, a questionnaire survey was conducted among the local population in order to identify their level of awareness of the role of cultural heritage in local sustainable development, and the importance of their participation, as well as, their willingness for participatory activities.

Among several villages in the vicinity of Takht-e Soleyman WHS, Nosratabad village was targeted for the questionnaire survey since the main stakeholders of the rural cultural landscape are settled there. Due to its short distance from the main historical site, the inhabitants of this village have the highest interactions with the indirect and direct effects of the site, like tourism, expansion limitations, and considerations for economic growth.

The questionnaires were submitted to a target group of 82 inhabitants (around $10 \%$ of the total population of the Nosratabad village), out of which 12 were considered to be biased since they incomplete and thus they were excluded from the final analysis.

The closed-ended questions were designed in the form of 5-point Likert scale, permitting a quantitative analysis of the qualitative viewpoints. The questionnaire was administered in the Persian language and back translated to English. For the final analysis the SPSS program was used.

The following questions were posed based on the literature and results of the interviews:

1- Can the cultural heritage of Takht-e Soleyman be considered as a wealth for the future generations? (Q1)

2- How much has economic, cultural and social development been improved by the cultural heritage in Takht-e Soleyman? (Q2)

3- Does the participation of the local community in WHS management speed up local development? (Q3) 
4- How much are you interested in taking a role in the preservation of cultural heritage and its rational exploitation, such as the development of the tourism industry in your region? (Q4)

In Q1 and Q2, the respondent's awareness about the role of cultural heritage in sustainable development is implicitly evaluated by asking if they consider cultural heritage as a resource for the development of their region at present and in the future. In other words, how they connect the meaning of valorization of cultural heritage and sustainable development.

In Table 1, the average value of the answers to each of the first two questions can be observed (4.04, 2.37 respectively). The average of the mentioned values, 3.205, indicates the level of awareness of the local community about the role of cultural heritage in local sustainable development. The deviation from the mean value of $3(+1.04)$ shows that the respondent group has quite acceptable awareness regarding cultural heritage as a resource for future generations $(\mathrm{Q} 1)$, while they believe that the cultural heritage does not yet have a very high impact on social, cultural and economic development of their region (Q2). The average of Q3 and its deviation from the mean value of 3, (-1.7), show that the importance of participation is not highly perceived. However, the average and deviation of Q4 (3.07 and +0.07 respectively) show a medium level of local community willingness for participatory activities.

\section{Please insert Table 1. here}

Appendix A presents the tables of quantitative data analysis regarding Q1 to Q4.

\section{Discussion}

In this section, the results of the empirical survey are discussed in order to assess the state of implementation of the policy documents, as well as, the state of governance and management in Takht-e Soleyman with regard to local community engagement.

The review of the most relevant upstream national and regional policy documents showed that both the role of cultural heritage in local sustainable development, and the importance of local community engagement are considered in the majority of documents.

For instance, the role of cultural heritage in local sustainable development is addressed by national documents such as, The Fourth Economic, Social, and Cultural Development plan of the Islamic Republic of Iran (2005-2009), and the National Plan for Development of Tourism Industry, as well as, in regional documents, like the Horizon for Development of the West Azerbayjan Province. However, it is quite remarkable that this consideration is excluded from the The Fifth Economic, Social, and Cultural Development plan of the Islamic Republic of Iran (2011-2015).

As for the participation of the local community, there are specific considerations in national and regional documents like the National Development Vision 1404, the National Plan for Tourism Development, Vision for the West Azerbayjan Province, and the Iranian Cultural Heritage Organization Charter, 1988.

The results of the empirical study indicated some inconsistencies between those documents and the activities in place.

The results of Q1 demonstrated quite considerable awareness of the topics amongst the two groups of stakeholders (managers and local community), while the answers to Q2 and Q3 indicated that these activities are not concretely in place. The responses to Q2 represented that the role of cultural heritage in local development has not been realized to the level of its capacities. The result of Q3 indicated that 80\% of the local community put importance on the role of their participation in fostering local sustainable 
development (Table 4, Appendix A), but that they are not sufficiently involved. Hence, the questionnaire survey reflected a high potential for promoting such policies even given the fact that they have not been actuated up to this time.

Moreover, the real situation illustrated by the interviewees showed discrepancies between the considerations in policy documents and the present situation, as well. They argued that potential reasons could be: political orientations, inter-organizational problems (ICHHTO), short-term planning prospective, lack of awareness-raising programs, and lack of strategies and mechanisms for implementation of the existing policies.

This discrepancy was evident in analyzing the governance system of the site. Accordingly, the governance system of the site is organized in the manner of a hierarchical system, in which the local community is helpless in the decision-making processes and in the enhancement of the cultural heritage management and local development. It is based on a top-down approach without enough consideration of the role of local community and the private sector. There is neither a structured body or committee nor formalized activities focused on local community engagement. At present, all the legislation, administration, execution and monitoring is conducted directly by the governmental sector without any delegation to the local community who have indicated a high willingness to be engaged in the activities related to the WHS and the development of their region, made clear from the result of Q4.

One of the important reasons for this situation is the narrow source of expertise in Takht-e Soleyman WHS. The competencies involved during different periods were confined to archeology, architecture, history, conservation, and restoration. While this combination of expertise is important to control the state of preservation and conservation of the site, other competencies in the fields of general management, tourism management, event planning, economics as well as other disciplines in natural sciences and humanities (like sociology, psychology, and ethnology), which could strengthen community involvement, are missing. The combination of these competencies could enable the management system to better focus on participatory management of cultural heritage aiming at local sustainable development.

This lack of competencies emerges quite clearly from the analysis of the structure and content of the Takht-e Soleyman management plan. A management plan is the fundamental tool for addressing the activities of WHSs. It is used to coordinate protective legislation, administrative practices, management mechanisms, and local economic development strategies for the preservation and valorization of every WHS (UNESCO, 1994). It has to be considered as a guide for the day-to-day decision-making process concerning management of the WHS, rather than a single conservation plan (Pereira Roders and Van Oers, 2011).

The first management plan of Takht-e Soleyman WHS was prepared in 2003. It foresees initiatives for raising the awareness of local authorities and the public about the values of the site and the aims and importance of sustainable development. However, the importance of the role of local community is not highlighted in that document as the focus point of the management system. In the revision made on the management plan in 2010, it was expected that in the perspective of long-term planning (15 years) all the affairs related to administration, tourism, culture, conservation and research, investment and environment sector would be delegated in part to the local community. According to this study the strategies and mechanisms for this integration are not clearly elaborated in the aforementioned document. This is a deficiency that puts the achievement of this goal under question.

\section{Conclusions}


Landscapes are no longer a notion of geographical territory or even an artistic perception of the land. They are formed and maintained according to the way they are experienced by human being. Accordingly cultural landscapes are not only territories of cultural interest to be preserved but also they are understood and considered as an element of competitiveness at both local and national levels in virtue of being an integrated system of cultural, social, and economic values. This is more evident in the case of cultural landscapes with rural characteristics based on of their strong community-based value systems and the intrinsic local cultural, social, economic, and environmental values bound to the rural cultural heritage. This concern was more relevant to the case of traditional rural cultural landscapes and even more challenging when they are considered as WHSs.

On the other hand, the growing trend of participatory governance and management is observed in many sectors including cultural heritage. Participatory governance and management, as a relevant approach to sustainable development and decision-making process should necessarily be applied to rural cultural landscapes. A rural cultural landscape is an amalgamation of culture, nature, and rural life sustained through both inter-community relations and relations between the communities and the surrounding environment. Its uniqueness is derived in part by the focused, community-based value systems that can influence the intangible features of the cultural landscape, as well as, the social, cultural, and economic dimensions. Therefore, a participatory governance and management system that places the community member as one of the core concerns of sustainable development is an essential choice in the case of rural cultural landscapes. This approach paves the way towards achieving the sustainable development goals whilst preserving the cultural and environmental heritage elements of the rural cultural landscape. In contrast, the marginalization of the local community and their disengagement disintegrates the existing bonds connecting important features within the rural cultural landscape.

In line with the theorethical concerns of this research, the empirical survey was developed within the context of of Takht-e Soleyman WHS. This place is significant for embedding tangible cultural heritage of a long history, sacred features related to an important Persian faith and many other cultural features entangles with natural elements. It also encompasses significant natural elements as well as intangible cultural features. The challenging issue about this place was the low pace of development despite the high potentials and values.

The empirical part was composed of a set of interviews and a questionnaire survey based on a participatory approach inclusive of the viewpoints of managers and the local community.

However, our investigation shows a gap between what has been stated in the theoretical framework and the results of the empirical analysis. Indeed, the Takht-e Soleyman WHS case points out an inconsistency between the theory and policy documents, and the actual governance and management approaches. The role of cultural heritage in sustainable development and the importance of participatory governance and management were mentioned in many of the upstream national policy documents and were acknowledged by the interviewees and local community respondents. However, our results demonstrate a level of the community participation that is lower than was recommended by the upstream national policy documents and stated by our interviewees. Furthermore, the unique cultural heritage of the area is under-utilized, to the detriment of local socio-economic development.

The governance system of the site is plagued by a hierarchical mindset in which the local community does not yield any real influence in the decision-making process. It is based on a top-down approach without credence in the role of the local community, contrary to what is stated in the international documents and national policies. The management plan of Takht-e Soleyman WHS presents indications of participation of the local community, however no strategies and mechanisms are proposed in the implementation of the intended levels of the local participation. Hence, the Takht-e Soleyman WHS governance and management system currently in place has failed to create interfaces between the cultural 
landscape and sustainable development. This has largely led to a reduction in the feeling of attachment to the place among the local community, which in turn endangers the rural features of the place itself.

The following proposed measures might assist in addressing the above concernsto transition the Takhte Soleyman WHS into a participatory governance and management model:

- An integrated value-driven approach;

- Enhancing the involvement of the local community; and

- Further development of the existing management plan

These would also bring the Takht-e Soleyman WHS closer and closer to the international community debate.

The governance and management of rural cultural landscapes in a sustainable development perspective could integrate all the local values both at the national and regional organizational levels. A strong collaborative initiative is required both at an inter- and intra-organizational level, in order to promote a governance, management, planning, measurement and control system, in a long-term view. The outcome is a joint economic and cultural development interpretation of the outstanding cultural and natural heritage of Takht-e Soleyman WHS.

The awareness-raising program is the fundamental step in making alterations in existing situation. This process should start to be developed through a simultaneous top-down and bottom-up approach. The awareness raising programs are helpful in setting common visions among stakeholders. The value-driven approach inclusive of different stakeholders will be developed based on common visions while it results in producing knowledge at different level of players in sustainable development process.

The governance system of the area could become collaborative and community-based by making modifications to the formal management structure (i.e. by implementing a committee for local community participation) and by developing collaborative activity programs.

With reference to management, it is important to project a vision of joint economic and cultural development by valorizing the rich cultural endowments of this region. Another crucial factor is to develop competencies through the employment of personnel belonging to relevant disciplines such as economics and management, tourism management, event planning, sociology, psychology, natural sciences, and ethnology, as well as, to foster awareness raising mechanisms like education and training programs.

To overcome the above-mentioned issues, it is necessary to improve the existing policies, which redesign the governance and management approach in terms of broader emphasis on participation and more practical relevant considerations.

Apart from the national and local policies, the Management Plan of the WHS is an important normative instrument for implementation the relevant strategies. The Management Plan of Takht-e Soleyman WHS could be developed through an integrated approach including all the natural and cultural endowments within the UNESCO buffer zones, and emphasizing the role of the local community in a more practical way. For this purpose, the strategies and mechanisms regarding collective decision-making and local community participation should be incorporated into the management plan. It can be developed by defining the role of the local councils in the management of the site, and devoting a separate section to elaborate the mechanisms for local community engagement.

The universal values of Takht-e Soleyman could be improved to promote and elevate its consideration within the international community. The enhancement of strategies and mechanisms in terms of social 
dimension of heritage and community-led development could be confirmed and accelerated by referring to the available international documents and debates on achieving sustainable development goals and cultural heritage management (e.g. UN Agenda 21, 1992, 'The Future We want', 2012 and EU Presidency conference on Heritage Commons towards a Participative Heritage Governance in the Third Millennium, 2014).

This would help to unlock the potential of Takht-e Soleyman WHS, fostering both economic development and social inclusion.

\section{Notes}

[i] In the Iranian calendar, year 1404 corresponds to 2025 in the Gregorian calendar.

[ii] However, there has been a swinging approach in some of the upstream national development documents emphasizing the role of cultural heritage for a sustainable development: ironically enough, the role of cultural heritage for sustainable development had been better illustrated in the Fourth Economic, Social, and Cultural Development plan of Islamic Republic of Iran (2005-2009) than in the Fifth Economic, Social, and Cultural Development plan of Islamic Republic of Iran (2011-2015).

\section{References}

Antrop, M. (2005), "Why landscapes of the past are important for the future", Landscape and urban planning, Vol. 70 No. 1, pp. 21-34.

Badia, F. and Donato F. (2013), "Performance Measurement at World Heritage Sites: Per Aspera ad Astra", International Journal of Arts Management, Vol. 16 No. 1, pp. 20-33.

Bandarin, F., Hosagrahar, J. and Sailer Albernaz, F. (2011), "Why development needs culture", Journal of Cultural Heritage Management and Sustainable Development, Vol. 1 No. 1, pp. 15-25.

Belluso, R. (2012), "The geographic landscape as cultural heritage in the post-modern age", Almatourism: Journal of Tourism, Culture and Territorial Development, Vol. 1 No. 5, pp. 17-27.

Bemanian, M., Ansari M. and Almasifar N. (2010), "Rehailitation of Takht-e Soleyman Cultural (Historical) Landscape", Urban Management, Vol. 8 No. 26, pp. 7-26.

Besana, A. (2013), Economia del Turismo Culturale, Edizioni Unicopli, Italia.

Camarinha-Matos, L. M. and Macedo, P. (2010), "A conceptual model of value systems in collaborative networks", Journal of Intelligent Manufacturing, Vol. 21 No. 3, pp. 287-299.

Cervelló-Royo, R., Garrido-Yserte, R. and Segura-García del Río, B. (2012), "An urban regeneration model in heritage areas in search of sustainable urban development and internal cohesion", Journal of Cultural Heritage Management and Sustainable Development, Vol. 2 No. 1, pp.44-61.

Cervelló-Royo, R. \& Peiró-Signes, Á. (2015), "Environmental impact of coastline tourism development in Spain" in Parsa H. G. (eds.), Sustainability, Social Responsibility, and Innovations in the Hospitality Industry, Apple Academic Press, pp. 151-168.

Chhotray, V. and Stoker G. (2009), Governance Theory and Practice A Cross-Disciplinary Approach, Palgrave Macmillan, Houndsmills.

Cristina Heras, V., Wijffels, A., Cardoso, F., Vandesande, A., Santana, M., Van Orshoven, J., Steenberghen, T. and van Balen, K. (2013), "A value-based monitoring system to support heritage conservation planning", Journal of Cultural Heritage Management and Sustainable Development, Vol. 3 No. 2, pp. 130-147.

Dailoo, S. I. and Pannekoek, F. (2008), "Nature and Culture: A New World Heritage Context", International Journal of Cultural Property, Vol. 15 No. 1, pp. 25-47. 
Dewulf, G., Baarveld, M. and Smit, M. (2013), "Planning and commitment in cultural heritage projects", Journal of Cultural Heritage Management and Sustainable Development, Vol. 3 No. 2, pp. 163174.

Donato, F., Badia, F. (2008), La Valorizzazione dei Siti Culturali e dei Paesaggio, Leo S. OLSCHKI Editore, Firenze.

Dongier, P., Van Domelen, J., Ostrom, E., Ryan, A., Wakeman, W., Bebbington, A., Alkire, S. Esmail, T and Polski, M. (2003), Community driven development, World Bank Poverty Reduction Strategy Paper.

Fischer, F. (2006), "Participatory Governance as Deliberative Empowerment: The Cultural Politics of Discursive Space", American Review of Public Administration, Vol. 36 No.1, pp. 19-40.

Fowler, P. (2002), "World heritage cultural landscapes, 1992-2002: A review and prospect" in World Heritage Papers No. 7: Cultural Landscapes: The Challenges of Conservation, UNESCO, pp. 1630.

Fraser, E. D., Dougill, A. J., Mabee, W. E., Reed, M., and McAlpine, P. (2006), "Bottom up and top down: Analysis of participatory processes for sustainability indicator identification as a pathway to community empowerment and sustainable environmental management", Journal of environmental management, Vol. 78 No. 2, pp. 114-127.

Giuliani, M. V. and Feldman, R. (1993), "Place attachment in a developmental and cultural context", Journal of Environmental Psychology, Vol. 13 No. 3, pp. 267-274.

Greffe, X. (2010). "Urban Cultural Landscapes: An Economic Approach", Working paper, Dipartimento di Economia "S. Cognetti de Martiis", International Centre for Research on the Economics of Culture, Institutions, and Creativity (EBLA), Centro Studi Silvia Santagata (CSS), Italy.

Halfacree, K. H. (1995), "Talking about rurality: social representations of the rural as expressed by residents of six English parishes", Journal of Rural Studies, Vol. 11 No. 1, pp. 1-20.

Hens, L. (2005), "The Rio declaration on environment and development", Regional sustainable development review: Africa, Eolss Publishers, Oxford, UK.

Hummon, D. M. (1992), Community Attachment, Springer, US.

ICHO (Iranian Cultural Heritage Organization) (2002), "Takht-e Soleyman Fire Temple of Knights." UNESCO World Heritage Convention Nomination of Properties for Inclusion on the World Heritage List., Iranian Cultural Heritage Organization, Tehran, available at http://whc.unesco.org/uploads/nominations/1077.pdf (accessed 14 April 2015).

Kooiman, J. (Ed.) (1993), Modern Governance: New Government-society Interactions, Sage publications, University of Michigan.

Lokocz, E., Ryan, R. L., \& Sadler, A. J. (2011), "Motivations for land protection and stewardship: Exploring place attachment and rural landscape character in Massachusetts", Landscape and urban planning, Vol. 99 No. 2, pp. 65-76.

Millar, S. (2006), "Stakeholders and community participation", in Leask, A. and Fyall, A. (eds.), Managing world heritage sites, Butterworth-Heinemann (imprint of Elsevier), UK, pp. 37-54.

Mitchell, N., Rossler, M., \& Tricaud, P. M. (eds.) (2009), World Heritage paper No.26: World Heritage Cultural Landscapes. A handbook for conservation and management, UNESCO.

Murzyn-Kupisz, M., and Dzialek, J. (2013), "Cultural heritage in building and enhancing social capital", Journal of Cultural Heritage Management and Sustainable Development, Vol. 3 No.1, pp. 35-54.

Ostrom, E. (1993), "A communitarian approach to local governance", National Civic Review, Vol. 82 No. 3, pp. 226-233.

Palang, H., Alumäe, H. and Mander, Ü. (2000), "Holistic aspects in landscape development: a scenario approach", Landscape and Urban Planning, Vol. 50 No. 1, pp. 85-94.

Palang, H. and Fry G. (eds.) (2003), Landscape Interfaces: Cultural Heritage in Changing Landscapes, Kluwer Academic Publishers (imprint of Springer), Netherlands. 
Palang, H., Helmfrid, S., Antrop, M., and Alumäe, H. (2005), "Rural landscapes: past processes and future strategies", Landscape and urban planning, Vol. 70 No. 1, pp. 3-8.

Perkin, C. (2010), "Beyond the rhetoric: negotiating the politics and realizing the potential of community-driven heritage engagement", International Journal of Heritage Studies, Vol. 16 No. 12, pp. 107-122.

Pereira Roders, A. \& Van Oers, R. (2011), "World heritage cities management", Facilities, Vol. 29 No. 7-8, pp. 276-85.

Rosenau, J. N., \& Czempiel, E. O. (eds.) (1992), Governance without Government: Order and Change in World Politics (Vol. 20), Cambridge University Press, Cambridge.

Rössler, M. (2006), "World heritage cultural landscapes: a UNESCO flagship programme 19922006", Landscape Research, Vol. 31 No. 4, pp. 333-353.

Sauer, C. O. (1925), The Morphology of Landscape, University of California Press.

Selman, P. (2004), "Community participation in the planning and management of cultural landscapes", Journal of environmental planning and management, Vol. 47 No. 3, pp. 365-392.

Smith, L., Morgan, A., \& van der Meer, A. (2003), "Community-driven research in cultural heritage management: the Waanyi women's history project", International Journal of Heritage Studies, Vol. 9 No. 1 , pp. 65-80.

Swensen, G. and Stenbro, R. (2013), "Urban planning and industrial heritage-a Norwegian case study", Journal of Cultural Heritage Management and Sustainable Development, Vol. 3 No. 2, pp. 175-190.

Termorshuizen, J. W. and Opdam, P. (2009), "Landscape services as a bridge between landscape ecology and sustainable development", Landscape Ecology, Vol. 24 No. 8, pp. 1037-1052.

Throsby, D. (2012), "Article 13: Integration of Culture in Sustainable Development", in Von Schorlemer S. and Stoll P.-T. (eds.), The UNESCO Convention on the Protection and Promotion of the Diversity of Cultural Expressions, Springer Berlin Heidelberg, pp. 361-370.

UCLG and Barcelona City Council. (2009), "Culture and Sustainable Development: Examples of Institutional Innovation and Proposal of a New Cultural Policy Profile", available at http://www.agenda21culture.net (accessed 14 April 2015).

UNCED (United Nations Conference on Environment and Development) (1992), "Agenda 21".

UNCED (United Nations Conference on Environment and Development) (1992), "Rio Declaration".

UNCSD (United Nations Conference on Sustainable Development or Rio +20) (2012), "The Future We Want".

UNESCO. (2011), "Historic Urban Landscape Recommendation".

UNESCO (2012), "UN System Task Team on the post-2015 UN Development Agenda: Culture: a driver and an enabler of sustainable development", available at http://www.unesco.org/new/fileadmin/MULTIMEDIA/HQ/post2015/pdf/Think_Piece_Culture.pdf (accessed 14 April 2015).

UNESCO (1994), “Operational Guidelines for the Implementation of the World Heritage Convention".

Von Droste, B., Plachter, H., and Rössler, M. (eds.) (1995), Cultural Landscapes of Universal Value: Components of a Global Strategy, Fischer Verlag, Jena.

Vos, W. and Meekes, H. (1999), "Trends in European cultural landscape development: perspectives for a sustainable future", Landscape and urban planning, Vol. 46 No. 1, pp. 3-14.

Yung, E. H. and Chan, E. H. (2011), "Problem issues of public participation in built-heritage conservation: Two controversial cases in Hong Kong", Habitat International, Vol. 35 No. 3, pp. 457-466.

Please insert Appendix A here 
